\title{
Condition assessment of selected reinforced concrete structural elements of the bus station in Kielce
}

\author{
Pawet Tworzewski ${ }^{1,}$, Wioletta Raczkiewicz ${ }^{1}$, Wioletta Grzmil ${ }^{1}$, and Przemysław Czapik $^{1}$ \\ ${ }^{1}$ Kielce University of Technology, Faculty of Civil Engineering and Architecture, al. Tysiąclecia \\ Państwa Polskiego 7, 25-314 Kielce, Poland
}

\begin{abstract}
The paper presents the results of the research aimed at assessing the condition of reinforcement and concrete cover in selected elements of the structure of the most recognizable structure in Kielce, i.e. PKS station, located at Czarnowska Street. Currently, demolition works are underway resulting from the planned modernization. The assessment of the corrosion risk of the reinforcement in the construction elements was carried out with the use of a semi-non-destructive electrochemical method. The use of this method made it possible to determine the probability of reinforcement corrosion in the selected areas and to estimate its rate. The protective properties of concrete cover were checked by the carbonation test (test using a $1 \%$ phenolphthalein solution) and phase composition analysis (X-ray diffraction analysis). In order to determine the position of the reinforcing bars and to estimate the concrete cover thickness distribution in the areas corresponding to the aforementioned measurements, ferromagnetic detection system was used.
\end{abstract}

\section{Introduction}

The construction project of the bus station in Kielce was made by the "Miastoprojekt" Kielce design office in the first half of the 1970s. One of the main assumptions made by the main designer, Mieczysław Kubala, was to create a collision-free movement, which led to the design of circular motion around the building and directly influenced its shape. The result was the bus station with a unique shape that became the showcase of the Kielce city.

The supporting structure of the station is made up of two independent parts (Figure 1 and 4): reinforced concrete internal structure and a bar structure of the steel domes of the roofing. The main building has the shape of a cylinder, consisting of three levels: cash register, platform and entresol. The station's roof was designed in the form of two interpenetrating domes supported by ten arched supports. The net internal area of the main building is $1800 \mathrm{~m}^{2}$, while the usable floor area is $6100 \mathrm{~m}^{2}$. Additional information on the object, including details of the steel parts of the structure, is presented in the works of Modrzejewski, Radkiewicz and Sieczkowski [1] and Banachowska [2].

\footnotetext{
*Corresponding author: ptworzewski@tu.kielce.pl
} 
Currently part of the bus station is subject to demolition. These works are aimed at preparing the facility for modernization and reconstruction. Owing to the fact that the authors of the paper obtained permission to enter the facility and access some of the rooms, it was possible to diagnose selected reinforced concrete elements of the supporting structure. The paper presents the results of testing for some of the elements such as reinforced concrete slabs and columns. The study included the measurement of the thickness of the cover, the assessment of reinforcement by electrochemical method, the phase composition of the concrete cover by XRD (X-ray diffraction method) and the depth of carbonation with a $1 \%$ phenolphthalein solution.



Fig. 1. PKS bus station in Kielce under construction (photo provided by E. Modrzejewski).

\section{Description of the tests}

The assessment of the reinforcement corrosion risk in the tested elements was carried out by means of an galvanostatic pulse method [3-7]. This method was developed based on the assumption that the corrosion process of reinforcement in concrete is an electrochemical process (a steel reinforcing bar acts as an electrode, and the alkaline liquid filling the pores of the concrete is an electrolyte). The local anode and cathode microcells which appear on the surface of the rod, generate electric charge through the rod, while the liquid filling the pores of the concrete is the carrier of ions. The assessment of the process advancement is based on the measurement of certain electrical quantities characterizing the corrosion process, and their comparison with the base values. Due to the need to connect the measuring device with the tested rod, it is necessary to uncover the reinforcing bars on a few-centimeter long section. These tests belong to the so-called semi-non-destructive tests, because they damage the tested element to a minor but easy to repair extent.

The GP-5000 GalvaPulse ${ }^{\mathrm{TM}}$ device shown in Figure 2a was used. It ensures simultaneous and relatively fast measurement of three electrical quantities: the potential of stationary reinforcement $\left(\mathrm{E}_{\mathrm{st}}\right)$, resistivity of the concrete cover $(\Theta)$ and the corrosive current density $\left(i_{\text {cor }}\right)[8,9]$. GalvaPulse kit allows conducting two types of measurements: 
- basic, including measurement of the stationary potential of reinforcement and resistivity of concrete cover (which makes it possible to assess with certainty whether there are corrosive conditions in the tested area),

- advanced measurement, during which, in addition to the abovementioned values, the corrosive current density is measured (on the basis of which the corrosive activity of the reinforcement can be determined and its rate over time).

In order to obtain reliable results, it is recommended to perform advanced measurement. The database of reference results with which the measured values are compared is shown in Table 1.

Material studies included:

- determination of carbonation using a $1 \%$ phenolphthalein solution on a fresh concrete surface immediately after removal of the concrete cover (in accordance with PN-EN 13295: 2005 [10] and PN-EN 14630: 2007 [11]),

- laboratory determination of the phase composition of the concrete by X-ray diffraction analysis on a sample taken from a fragment of concrete cover.

The Hilti PS200 scanner was used to locate reinforcing bars in concrete (Figure 2b). Software added to the device helped to determine the thickness of the concrete cover. The device operates on the principle of electromagnetic induction [12, 13]. These measurements were made to assess deviations in the thickness of concrete covered in the tested areas. The deviations of the concrete cover thickness have a significant impact on the rate of loss of the concrete protective properties [14].

Table 1. Criteria for assessing the degree of reinforcement corrosion risk.

\begin{tabular}{|l|c|c|l|c|}
\hline \multicolumn{4}{|c|}{ Criteria for assessing the degree of reinforcement corrosion risk by use the galvanostatic pulse } \\
method
\end{tabular}



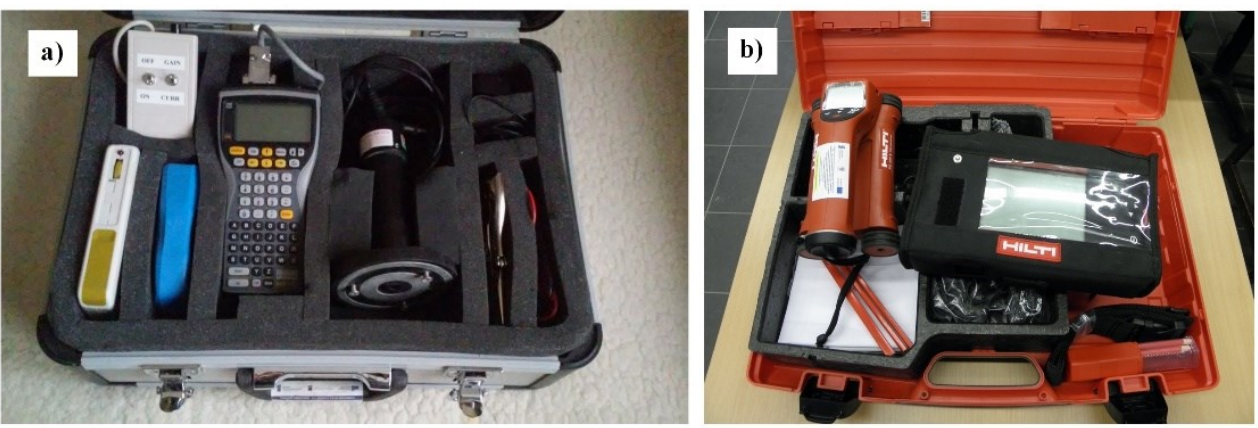

Fig. 2. Measuring devices: a) GP-5000 GalvaPulse ${ }^{\mathrm{TM}}$ kit, b) PS 200 Hilti scanner.

\section{Elements subjected to examination}
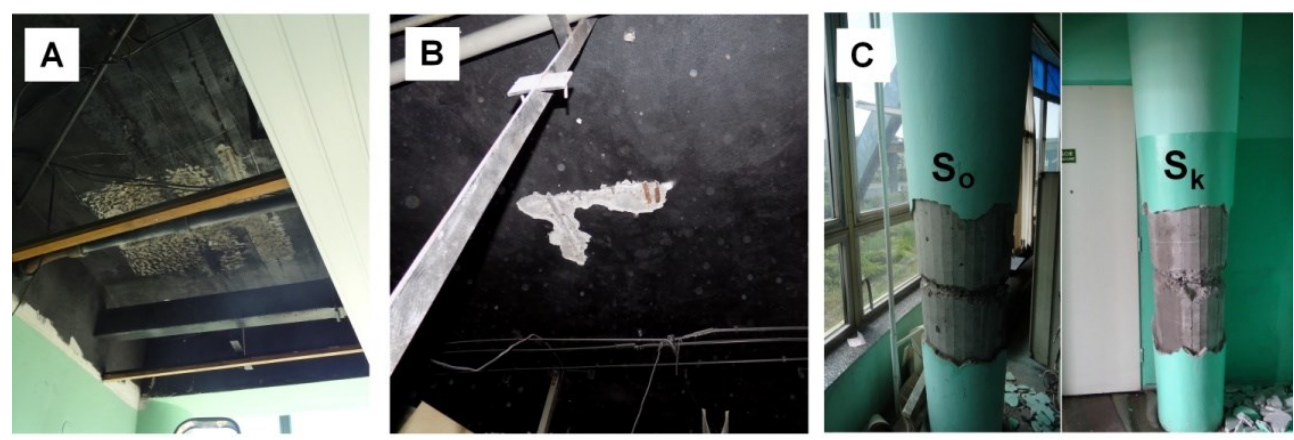

Fig. 3. Photos of tested elements: slab on level „0” (A), slab on level ,-1” (B) and columns $S_{o}$ and $S_{k}$ on level ,0" (C).

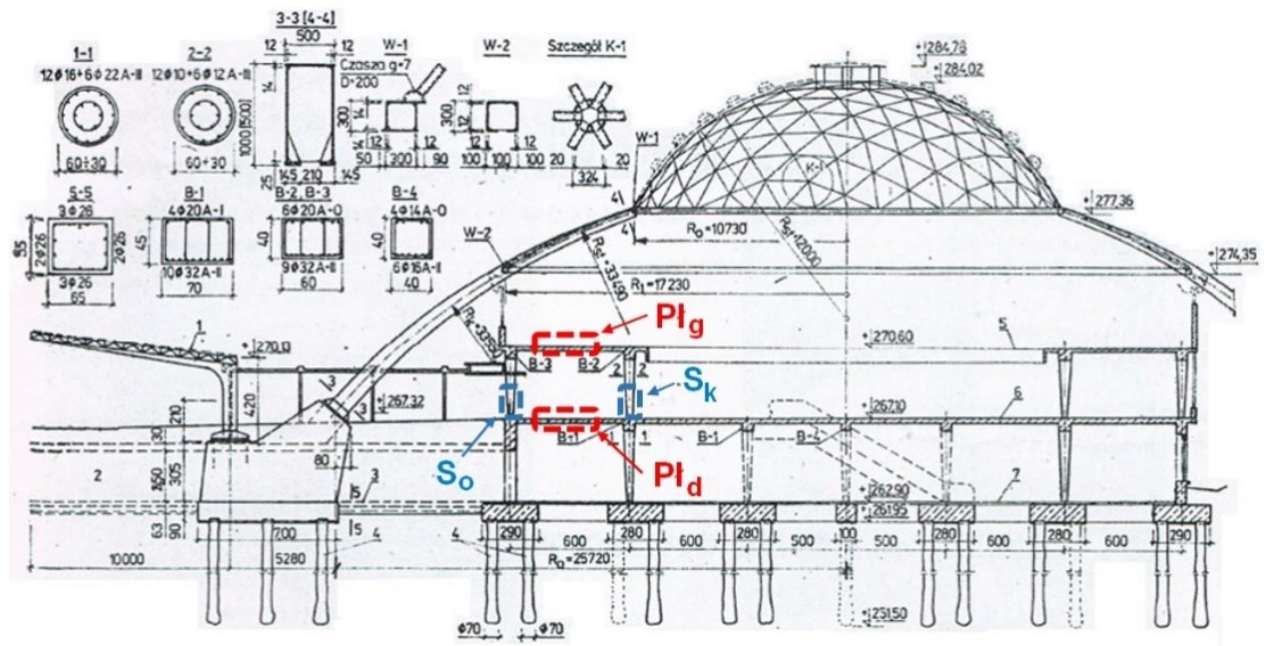

Fig. 4. Vertical cross-section of PKS bus station in Kielce [1].

Slab at level "0" (symbol: $\mathrm{P}_{\mathrm{g}}$ ) - the tested area with dimensions of about $0.6 \times 0.6 \mathrm{~m}$. The surfaces before the test were cleaned and then a $4 \times 4$ mesh with a mesh size $0.15 \times 0.15 \mathrm{~m}$ was applied. Based on it, scans were made using ferroscan device (the "Imagescan" function 
was used). After recognizing the arrangement of the reinforcing bars on a selected section of the slab, on the section $\sim 7 \div 10 \mathrm{~cm}$ wide, perpendicular to the main reinforcement direction, the concrete cover was removed. This made it possible to connect the GalvaPulse ${ }^{\mathrm{TM}}$ measurement set to rebar. On the area dedicated to the study, 6 measuring points were selected in a spacing of $\sim 10 \mathrm{~cm}$, located directly under each rod (a total of 30 measurement points). At five points $[(1,4),(1,5),(5,4),(5,5),(5,6)]$ it was not possible to perform the measurement, while in one point $(1,1)$, the measurement of concrete cover resistance exceeded $\Theta=50[\mathrm{k} \Omega \cdot \mathrm{cm}]$, which, according to the manufacturer's guidelines, excluded it from the analysis.

Slab at the "-1" level (symbol: $\mathrm{Pł}_{\mathrm{d}}$ ) - the area subjected to the test with dimensions of about $0.45 \times 0.45 \mathrm{~m}$. The area was prepared by removing the plaster, applying a $3 \times 3$ mesh (to perform the scan with the ferroscan device) and removing the concrete cover (section $\sim 5 \mathrm{~cm}$ wide), in order to reveal fragments of the bottom reinforcing bars (Figure 3 ). In this way, access to 5 bars was obtained. Along each of them, 5 measuring points were marked, with a spacing of $\sim 10 \mathrm{~cm}$, which gave a total of 20 points.

Reinforced concrete columns at the "0" level (symbol: $S_{o}$ and $S_{k}$ ). The preparation of the elements included the removal of the plaster at a height of about $0.80 \mathrm{~m}$, and then about $1 \mathrm{~m}$ from the level of the floor, the removal of the concrete cover. In this way 8 (out of 12) main reinforcement bars were exposed, which enabled their connection to the GalvaPulse ${ }^{\mathrm{TM}}$ measurement set. Along the line of each bar, 6 measuring points were spaced at $\sim 10 \mathrm{~cm}$, which gave a total of 48 measuring points on each element (Figure 3). The variable column width made it impossible to use the "Imagescan" function available in the ferroscan device. Therefore, only quick detection ("Quickscan") was carried out, i.e. one passage around the perimeter of the column cross-section.

Carbonation was determined on the fresh concrete surface immediately after removal of the concrete cover layers in the places described above. The test was carried out in accordance with $[10,11]$. On the surface of the concrete (cleaned of dust and loose particles and dew-sprinkled water), a 1\% phenolphthalein solution was applied using a sprinkler. The color change on the concrete surface was checked after approximately 30 seconds.

In addition, samples taken from the concrete cover were used to determine the pastes phase composition. For this purpose, the aggregate was separated from the milled samples. The studies in the Empyrean X-ray diffractometer from PANalytical were subjected to samples with a grain size less than $0.065 \mathrm{~mm}$. The tests were carried out using a $\mathrm{Cu}$ lamp and $\mathrm{X}^{\prime}$ Celerator detector in the range 5 to $55^{\circ} 2 \theta$. The step size during which the diffraction radiation was counted was $0.0167^{\circ}$ with a counting time of $45 \mathrm{~s}$.

\section{Obtained results}

The results of measurements made with the GP-5000 GalvaPulseTM measuring device are shown in Figure 5. For each measuring point marked with the coordinates (X, Y), the results are given for the following values:

- stationary reinforcement potential, $\mathrm{E}_{\mathrm{st}}[\mathrm{mV}]$ (upper value),

- corrosion rate, $[\mu \mathrm{m} / \mathrm{year}]$ (central value, automatically calculated from the measured corrosion current density),

- resistivity of concrete cover, $\Theta[\mathrm{k} \Omega \cdot \mathrm{cm}]$ (lower value).

Analysis of the results obtained for the slab at the level "0" (symbol: $\mathrm{Pt}_{\mathrm{g}}$ ) using GalvaPulse ${ }^{\mathrm{TM}}$ showed that:

- the stationary potential of reinforcement at no point exceeded $E_{\text {st }}=-200 \mathrm{mV}$, which indicates that the corrosion probability in the tested area did not exceed $5 \%$.

- the corrosion current density for values in 6 points was in the range of $i_{\text {cor }}<0.5 \mu \mathrm{A} / \mathrm{cm}^{2}$, which indicates "not forecasted corrosion activity of reinforcement"; values in the 
remaining 18 points were in the range of $\mathrm{i}_{\text {cor }}=0.5 \div 2.0 \mu \mathrm{A} / \mathrm{cm}^{2}$ which means "negligible corrosive activity"; the values obtained allow forecasting the corrosion rate at the level of $1.2 \div 19.4 \mu \mathrm{m} /$ year.

- resistivity of the concrete cover: reached values of $\Theta \geq 20 \mathrm{k} \Omega \cdot \mathrm{cm}$ in 9 points, which indicates a low probability of corrosion in the studied area; in 8 points it was in the range $\Theta=10 \div 20 \mathrm{k} \Omega \cdot \mathrm{cm}$, i.e. with the average probability of corrosion, but in 7 points the values were lower than $\Theta=10 \mathrm{k} \Omega \cdot \mathrm{cm}$, suggesting a high probability of corrosion.

Analysis for the reinforced concrete slab at level "-1" made on the basis of measurements in 20 points allowed to determine that:

- the values of stationary reinforcement potential in most of the points did not exceed $\mathrm{E}_{\mathrm{st}}=-$ $200 \mathrm{mV}$, which indicated no more than $5 \%$ corrosion probability in a given area, however in two points the measurements reached values from the range $E_{s t}=-350 \div-200$, suggesting $50 \%$ corrosion probability (according to Table 1 ).

- corrosion current density values at 3 points were smaller than $i_{\text {cor }}=0.5 \mu \mathrm{A} / \mathrm{cm}^{2}$, which indicated "not forecasted corrosion activity of reinforcement", in 13 points they were in the range of $\mathrm{i}_{\text {cor }}=0.5 \div 2.0 \mu \mathrm{A} / \mathrm{cm}^{2}$, meaning " negligible corrosive activity" (according to Table 1), but in 4 points exceeded the value of $i_{\text {cor }}=2,0 \mu \mathrm{A} / \mathrm{cm}^{2}$, which indicated "low corrosive activity of reinforcement". At the same time, the obtained values allow forecasting a corrosion rate of 0.5-29.2 $\mu \mathrm{m}$ /year.

- the measured resistivity of concrete cover at 2 points reached the value of $\Theta \geq 20 \mathrm{k} \Omega \cdot \mathrm{cm}$, which meant low probability of corrosion in the studied area; in 5 points it was in the range $\Theta=10 \div 20 \mathrm{k} \Omega \cdot \mathrm{cm}$, which meant the average probability of corrosion, but in 13 points the values were smaller than $\Theta=10 \mathrm{k} \Omega \cdot \mathrm{cm}$, which suggested a high probability of corrosion (Table 1).

Studies of two columns made based on measurements at 43 points in the $S_{o}$ and 48 points in the $\mathrm{S}_{\mathrm{k}}$ (Figure 5) were comparable and showed that:

- the stationary potential of reinforcement at no point in both columns exceeded $E_{\mathrm{st}}=-200 \mathrm{mV}$, which indicated no more than $5 \%$ probability of corrosion in a given area.

- corrosion current density at 19 points in the $S_{o}$ column and at 21 points in the $S_{k}$ column reached the value of $\mathrm{i}_{\mathrm{cor}}<0.5 \mu \mathrm{A} / \mathrm{cm}^{2}$, which indicated "not forecasted corrosion activity of the reinforcement"; in the remaining 24 points in the $\mathrm{S}_{\mathrm{o}}$ column and in 27 points in the $\mathrm{S}_{\mathrm{k}}$ column, it was in the range $\mathrm{i}_{\text {cor }}=0.5 \div 2.0 \mu \mathrm{A} / \mathrm{cm}^{2}$, meaning " negligible corrosive activity"; At the same time, the obtained values allow forecasting the rate of corrosion at the level of $1.3 \div 17.3 \mu \mathrm{m} /$ year in both elements.

- the resistivity of the concrete cover in 18 points in the $\mathrm{S}_{\mathrm{o}}$-column and in 24 points in the $\mathrm{S}_{\mathrm{k}}$-column reached values of $\Theta \geq 20 \mathrm{k} \Omega \cdot \mathrm{cm}$, i.e. a low probability of corrosion of the reinforcement; in 22 points in the $\mathrm{S}_{\mathrm{o}}$ and in 16 points in the $\mathrm{S}_{\mathrm{k}}$-column it was in the range $\Theta=10 \div 20 \mathrm{k} \Omega \cdot \mathrm{cm}$, i.e. with a average probability of corrosion, but in 3 points in column $S_{o}$ and in 8 points in the $S_{k}$ column the values were lower than $\Theta \leq 10 \mathrm{k} \Omega \cdot \mathrm{cm}$, suggesting a high probability of corrosion. 


\begin{tabular}{|c|c|c|c|c|c|}
\hline$n x$ & 1 & 2 & 3 & 4 & 5 \\
\hline 6 & $\begin{array}{c}74 \\
2,4 \\
41,9\end{array}$ & $\begin{array}{c}104 \\
1,2 \\
23,6\end{array}$ & $\begin{array}{c}96 \\
2,1 \\
31,4\end{array}$ & $\begin{array}{c}109 \\
8,0 \\
12,1\end{array}$ & EMPTY \\
\hline 5 & EMPTY & $\begin{array}{c}63 \\
3,4 \\
21,0\end{array}$ & $\begin{array}{c}57 \\
3,1 \\
19,0\end{array}$ & $\begin{array}{l}49 \\
5,8 \\
5,6 \\
\end{array}$ & EMPTY \\
\hline 4 & EMPTY & $\begin{array}{c}26 \\
8,1 \\
17,5\end{array}$ & $\begin{array}{c}25 \\
5,7 \\
15,7\end{array}$ & $\begin{array}{c}-14 \\
11,7 \\
4,4\end{array}$ & EMPTY \\
\hline 3 & $\begin{array}{c}-40 \\
6,6 \\
19,0 \\
\end{array}$ & $\begin{array}{c}14 \\
8,1 \\
11,6\end{array}$ & $\begin{array}{c}18 \\
6,4 \\
12,8 \\
\end{array}$ & $\begin{array}{c}-31 \\
19,4 \\
2,5\end{array}$ & $\begin{array}{c}-5 \\
10,9 \\
2,2 \\
\end{array}$ \\
\hline 2 & $\begin{array}{c}33 \\
8,3 \\
41,9 \\
\end{array}$ & $\begin{array}{c}37 \\
7,7 \\
20,8 \\
\end{array}$ & $\begin{array}{c}44 \\
6,4 \\
20,9 \\
\end{array}$ & $\begin{array}{l}48 \\
6,2 \\
3,2 \\
\end{array}$ & $\begin{array}{l}125 \\
5,4 \\
4,6 \\
\end{array}$ \\
\hline 1 & $\begin{array}{c}2493 \\
21,1 \\
0,0\end{array}$ & $\begin{array}{c}25 \\
8,8 \\
27,3 \\
\end{array}$ & $\begin{array}{c}62 \\
2,5 \\
34,1\end{array}$ & $\begin{array}{c}130 \\
9,4 \\
10,6\end{array}$ & $\begin{array}{c}133 \\
10,5 \\
9,9\end{array}$ \\
\hline
\end{tabular}

a) $\mathrm{Pl}_{g^{-}}$slab on level " 0 "

\begin{tabular}{|c|c|c|c|c|c|}
\hline$n x$ & 1 & 2 & 3 & 4 & 5 \\
\hline 6 & $\begin{array}{c}12 \\
0,6 \\
29,2 \\
\end{array}$ & $\begin{array}{r}-36 \\
7,5 \\
21,6 \\
\end{array}$ & $\begin{array}{r}-117 \\
5,8 \\
7,3 \\
\end{array}$ & EMPTY & $\begin{array}{r}-224 \\
3,7 \\
1,1 \\
\end{array}$ \\
\hline 5 & $\begin{array}{r}-48 \\
6,2 \\
11,5 \\
\end{array}$ & $\begin{array}{r}-40 \\
9,9 \\
12,9 \\
\end{array}$ & $\begin{array}{r}-88 \\
2,3 \\
3,2 \\
\end{array}$ & EMPTY & $\begin{array}{c}-192 \\
21,2 \\
0,9\end{array}$ \\
\hline 4 & EMPTY & $\begin{array}{c}-68 \\
17,4 \\
6,9\end{array}$ & $\begin{array}{l}-81 \\
9,2 \\
4,7 \\
\end{array}$ & EMPTY & $\begin{array}{c}-142 \\
44,0 \\
0,5\end{array}$ \\
\hline 3 & EMPTY & $\begin{array}{c}-106 \\
13,0 \\
5,2\end{array}$ & $\begin{array}{c}-101 \\
14,6 \\
3,9\end{array}$ & EMPTY & EMPTY \\
\hline 2 & $\begin{array}{l}-87 \\
12,6 \\
10,0 \\
\end{array}$ & $\begin{array}{c}-156 \\
10,6 \\
5,0 \\
\end{array}$ & $\begin{array}{c}-139 \\
26,3 \\
3,4 \\
\end{array}$ & EMPTY & EMPTY \\
\hline 1 & $\begin{array}{l}-70 \\
15,0 \\
14,3\end{array}$ & $\begin{array}{r}-102 \\
18,1 \\
13,5\end{array}$ & $\begin{array}{r}-108 \\
28,9 \\
4,4\end{array}$ & EMPTY & $\begin{array}{c}-164 \\
31,8 \\
1,2\end{array}$ \\
\hline
\end{tabular}

b) $\mathrm{Pl}_{\mathrm{d}^{-}}$slab on level "-1"

\begin{tabular}{c|c|c|c|c|c|c|c|c}
$n \mathbf{n n n n n n n}$ & $\mathbf{1}$ & $\mathbf{2}$ & $\mathbf{3}$ & $\mathbf{4}$ & $\mathbf{5}$ & $\mathbf{6}$ & $\mathbf{7}$ & $\mathbf{8}$ \\
\hline \multirow{6}{*}{$\mathbf{6}$} & 49 & 19 & 37 & 19 & 4 & 36 & 69 & 66 \\
& 3,3 & 5,6 & 5,9 & 4,3 & 5,8 & 4,4 & 3,1 & 3,4 \\
& 14,6 & 16,0 & 17,0 & 14,2 & 29,4 & 37,5 & 44,7 & 41,0 \\
\hline \multirow{3}{*}{$\mathbf{5}$} & 18 & -27 & -13 & -43 & -24 & -15 & 18 & 18 \\
& 6,3 & 5,8 & 5,4 & 4,7 & 5,4 & 5,8 & 4,0 & 2,6 \\
& 21,2 & 18,8 & 19,6 & 16,4 & 26,7 & 35,6 & 33,4 & 65,5 \\
\hline \multirow{3}{*}{$\mathbf{4}$} & -76 & -132 & -112 & -151 & -115 & -53 & -73 & -63 \\
& 10,2 & 9,6 & 17,3 & 12,1 & 6,6 & 7,4 & 3,6 & 3,9 \\
& 24,8 & 19,6 & 22,4 & 12,8 & 20,0 & 31,0 & 26,8 & 53,1 \\
\hline \multirow{3}{*}{3} & -92 & -99 & -45 & -64 & -80 & -95 & -106 & -20 \\
& 4,4 & 5,0 & 6,2 & 7,3 & 7,7 & 7,6 & 2,7 & 3,5 \\
& 31,5 & 17,7 & 18,0 & 8,9 & 14,9 & 10,1 & 5,9 & 60,5 \\
\hline \multirow{2}{*}{$\mathbf{2}$} & -6 & -5 & 45 & 21 & -18 & -27 & -59 & 12 \\
& 3,0 & 7,7 & 10,2 & 5,2 & 5,9 & 6,2 & 5,1 & 3,3 \\
& 47,7 & 19,6 & 25,1 & 13,7 & 12,9 & 10,5 & 19,7 & 68,1 \\
\hline \multirow{2}{*}{$\mathbf{1}$} & -1 & 33 & 72 & 38 & 7 & -12 & -19 & 19 \\
& 3,0 & 6,9 & 7,2 & 4,5 & 4,2 & 1,8 & 2,0 & 3,2 \\
& 56,2 & 25,6 & 37,7 & 17,8 & 19,8 & 5,4 & 17,0 & 90,7 \\
\hline
\end{tabular}

\section{c) So column}

\begin{tabular}{c|c|c|c|c|c|c|c|c|}
$\mathbf{n n n n n n n n}$ & $\mathbf{1}$ & $\mathbf{2}$ & $\mathbf{3}$ & $\mathbf{4}$ & $\mathbf{5}$ & $\mathbf{6}$ & $\mathbf{7}$ & $\mathbf{8}$ \\
\hline \multirow{3}{*}{$\mathbf{6}$} & 13 & 14 & 17 & 15 & 22 & 59 & 59 & 33 \\
& 2,6 & 8,2 & 7,9 & 6,7 & 1,3 & 6,5 & 8,6 & 12,0 \\
& 5,0 & 12,0 & 11,3 & 14,1 & 35,3 & 25,0 & 25,0 & 27,6 \\
\hline \multirow{3}{*}{$\mathbf{5}$} & -26 & -22 & -17 & -1 & -28 & 43 & 46 & 15 \\
& 4,5 & 4,3 & 8,6 & 3,5 & 1,4 & 5,1 & 9,5 & 10,3 \\
& 8,3 & 6,5 & 10,9 & 7,8 & 31,4 & 18,5 & 20,7 & 24,4 \\
\hline \multirow{3}{*}{$\mathbf{4}$} & -84 & -79 & -62 & -35 & -131 & -41 & 25 & -4 \\
& 6,0 & 10,5 & 5,6 & 6,7 & 1,5 & 10,0 & 10,9 & 12,9 \\
& 6,7 & 8,8 & 5,5 & 11,5 & 29,1 & 12,9 & 18,1 & 23,8 \\
\hline \multirow{3}{3}{$\mathbf{3}$} & -57 & -11 & 68 & 102 & -26 & 143 & 161 & 87 \\
& 7,7 & 7,7 & 8,5 & 6,0 & 1,4 & 8,1 & 8,9 & 11,7 \\
& 10,0 & 11,7 & 14,1 & 19,1 & 31,9 & 22,3 & 27,4 & 22,2 \\
\hline \multirow{2}{*}{$\mathbf{2}$} & 63 & 84 & 107 & 131 & -19 & 162 & 171 & 121 \\
& 3,6 & 3,9 & 5,0 & 5,3 & 1,8 & 7,0 & 8,9 & 8,7 \\
& 16,2 & 15,6 & 15,5 & 18,5 & 32,7 & 22,4 & 26,8 & 27,4 \\
\hline \multirow{2}{*}{$\mathbf{1}$} & 86 & 121 & 123 & 143 & -72 & 170 & 182 & 114 \\
& 2,7 & 2,9 & 4,1 & 4,2 & 1,7 & 5,7 & 7,8 & 6,9 \\
& 24,2 & 20,5 & 18,4 & 21,9 & 34,8 & 25,2 & 31,5 & 37,1 \\
\hline
\end{tabular}

d) Sk column

Fig. 5. Results tables generated by program GalvaPulse.

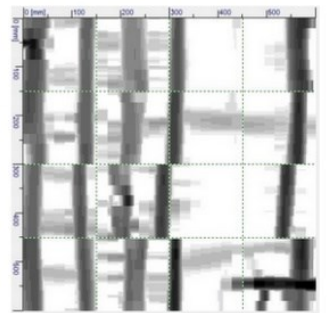

a) $\mathrm{Pl}_{\mathrm{g}}$ - slab on level " 0 "

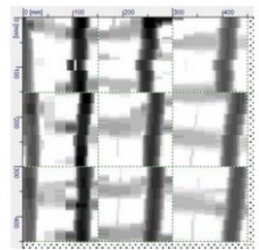

b) $\mathrm{PI}_{\mathrm{d}}$ - slab on level "-1"



c) So column

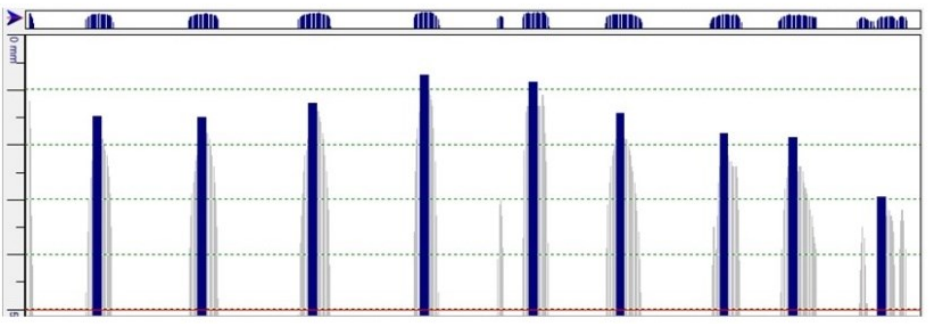

d) Sk column

Fig. 6. The image of the reinforcing bars location in the elements, obtained with the use of ferroscan device. 
On the basis of the scan carried out with the use of Hilti PS200 ferroscan and measurements carried out for exposed rods, it was found that ribbed bars with a diameter of $20 \mathrm{~mm}$ spaced every $10-15 \mathrm{~cm}$ were used as the main slabs reinforcement. As distribution reinforcement, smooth bars with a diameter of $8 \mathrm{~mm}$ were used. In the software included with the device (after introducing preliminary data of the diameter measurements of reinforcing bars), measurement of the thickness of the main reinforcement cover were made at 15 points. The obtained results are summarized in Table 2 . The reinforcing bars detection in graphical form are shown in Figure 6. Unfortunately, due to the lack of design documentation and information on the reinforcement used in the reinforced concrete slabs, verification of the obtained results was not possible.

According to the only available material shown in Figure 4, the columns should be reinforced with two rows of reinforcement (the inner ring of the reinforcing bars- 6 bars with a diameter of $12 \mathrm{~mm}$, the outer ring - 10 bars with a diameter of $10 \mathrm{~mm}$ ). The range of the scanner and the measurement taken after removing the concrete cover allowed for verification only of the outer layer bars (the number and diameter of bars corresponded to information from available sources [1]). Due to the difficult access to the side surface of the columns, the scanning range included only 9 bars in both elements (Figure 6). The results of concrete cover thickness measurement for detected bars in both columns are presented in table2. The deviation in the position of the external reinforcement layer in both columns was caused by the horizontal displacement of the reinforcement grid before or during concreting of elements (significant difference between the minimum and maximum concrete cover thickness values). This affects the high values of the coefficients of variation (Table 2).

Table 2. Concrete cover thickness for the slabs and columns.

\begin{tabular}{|c|c|c|c|c|}
\hline $\begin{array}{c}\text { Average } \\
\text { value } \\
\mathrm{c} \\
{[\mathrm{mm}]} \\
\end{array}$ & $\begin{array}{c}\text { Maximum } \\
\text { value } \\
\mathrm{c}_{\max } \\
{[\mathrm{mm}]}\end{array}$ & $\begin{array}{l}\text { Minimum } \\
\text { value } \\
\mathrm{c}_{\min } \\
{[\mathrm{mm}]} \\
\end{array}$ & $\begin{array}{c}\text { Standard } \\
\text { deviation } \\
\mathrm{s} \\
{[\mathrm{mm}]}\end{array}$ & $\begin{array}{c}\text { Coefficient of } \\
\text { variation } \\
V \\
{[\%]} \\
\%]\end{array}$ \\
\hline \multicolumn{5}{|c|}{ Slab Płg } \\
\hline 13.8 & 19 & 8 & 2.8 & 20 \\
\hline \multicolumn{5}{|c|}{ Slab $\mathrm{Pl}_{\mathrm{d}}$} \\
\hline 11.45 & 18 & 5 & 4.5 & $40 \%$ \\
\hline \multicolumn{5}{|c|}{ Column $\mathrm{S}_{\mathrm{o}}$} \\
\hline 15 & 30 & 7 & 7 & 46.67 \\
\hline \multicolumn{5}{|c|}{ Column $\mathrm{S}_{\mathrm{k}}$} \\
\hline 31 & 42 & 18 & 9 & 29.03 \\
\hline
\end{tabular}

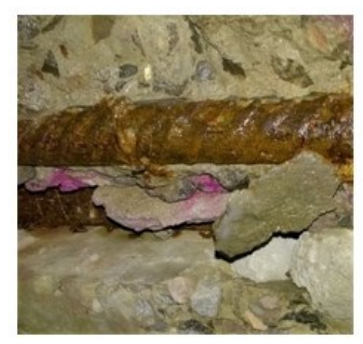

a) $\mathrm{Pl}_{\mathrm{d}}$ slab on level "-1"

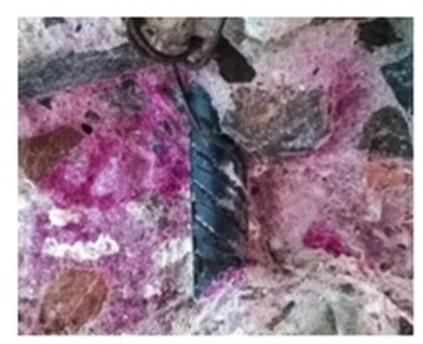

b) Sk column

Fig. 7. A photograph of a fragment of elements after the determination of carbonation with a $1 \%$ phenolphthalein solution: a) in the plate at level "-1"; b) in a reinforced concrete column. 


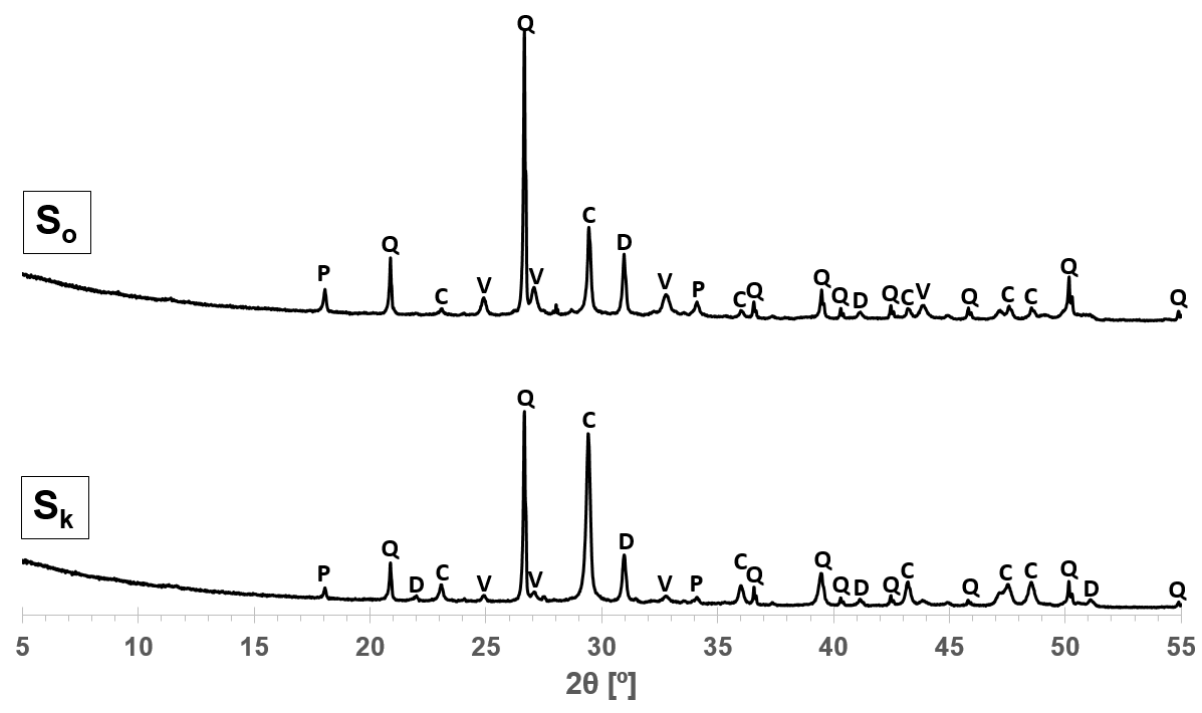

Fig. 8. R Diffractograms of pastes from concrete columns $S_{o}$ and $S_{k}$ : Q - quartz, C - calcite, D dolomite, $\mathrm{V}$ - vaterite, $\mathrm{P}$ - portlandite.

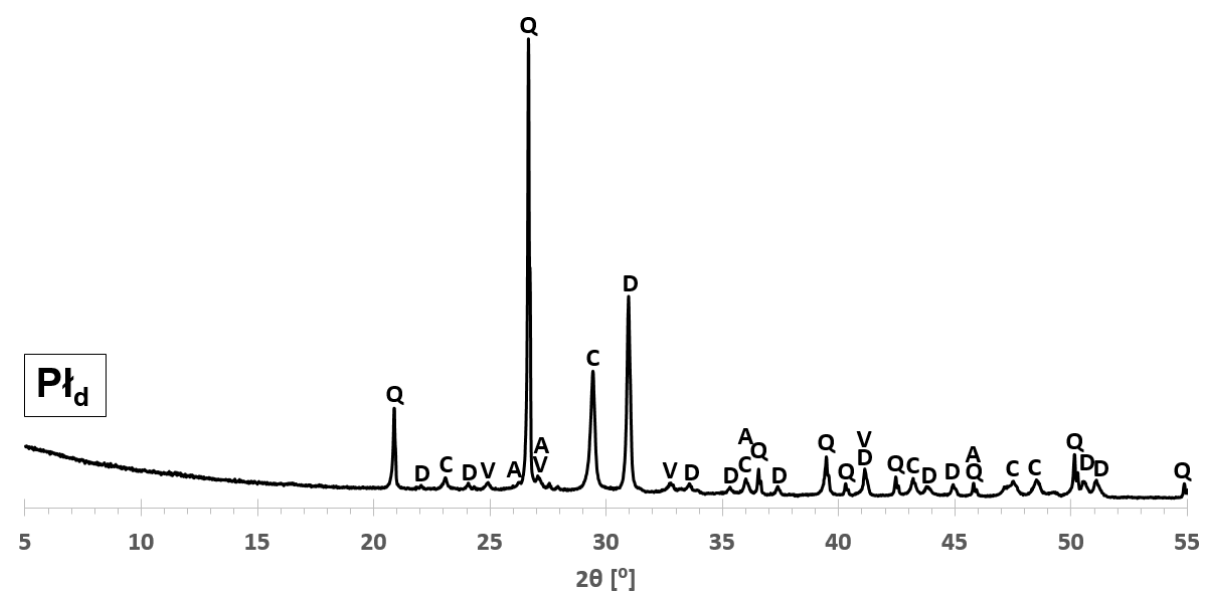

Fig. 9. Diffractogram of paste from “-1" concrete slab: Q - quartz, C - calcite, D - dolomite, V-vaterite, A - aragonite.

Investigations on the determination of carbonation showed that on the column surfaces the phenolphthalein solution turned purple, indicating a high $\mathrm{pH}$ of concrete (above 10), so the concrete cover was not carbonated (Figure $7 \mathrm{~b}$ ).

On the other hand, on the tested part surface on "-1" level slab, the concrete under the influence of a $1 \%$ phenolphthalein solution did not change (except for small point changes), which indicated carbonation and drop of the concrete $\mathrm{pH}$ below 8.5 (Figure 7a).

Diffractograms of the samples of pastes from columns and reinforced concrete slab are showed in Figure 8 and 9.

The analysis of the phase composition made by X-ray diffraction analysis showed that in samples from reinforced concrete columns, peaks caused by presence of aggregates dominates (silty fractions could not be separated during the preparation of test samples). On their basis, it was found that the aggregate used to make the concrete includes: quartz, calcite and dolomite. In all three concrete samples (two coming from reinforced concrete columns 
and one of the reinforced concrete slab from the level "-1"), a vaterite was found, which is formed as a transitional product during the carbonation of cement paste [15-20].

In the case of a sample from a reinforced concrete slab from level ,-1", the occurrence of calcium carbonate in the form of aragonite (which is formed as a result of carbonation) was also found. Calcite was also detected, which is also a polymorphic form of calcium carbonate that can be formed during carbonation. However, because its peaks were more intense than the dolomite peaks, its presence was connected with aggregate.

The lack of portlandite peaks presence on the plate $\mathrm{P}_{\mathrm{ld}}$ diffractogram also was a proof of the advanced carbonation process. Portlandite peaks were clearly visible on the columns diffractograms. Thus, it can be concluded that concrete from reinforced concrete slab has been carbonated to a greater extent than concrete from reinforced concrete pillars. The results of the phase composition test confirm the results of the carbonation test with the phenolphthalein solution.

It should also be emphasized that rooms on level ,-1"were located to a large extent below the ground level and were characterized by higher air humidity.

\section{Summary and conclusions}

The carried out studies included assessment of the corrosion risk of reinforcement supplemented by laboratory tests of concrete cover as well as field test with measurements of its thickness. These tests allowed a comprehensive assessment of the condition of selected reinforced concrete PKS station elements.

On the basis of the values of two parameters, no reinforcement corrosion risk was found in the slab and columns located at level " 0 " - values of corrosion current density indicated not forecasted or irrelevant corrosion activity of reinforcement and the value of stationary potential at a $5 \%$ probability of corrosion. On the other hand, in the slab at "-1" level, in some points, the corrosion hazard was greater - the values of the corrosion current density indicated low corrosion activity of the reinforcement and the stationary potential suggested $50 \%$ corrosion probability. The values of the third parameter, i.e. the resistivity of the concrete cover, in all the examined elements were varied and indicated both small, medium and high probability of corrosion. Probably, obtaining such values could be connected with demolition work and possible concrete damage (in the form of scratches and cracks), which was captured by the measuring device as lack of proper tightness of the concrete cover and high probability of corrosion.

The obtained results coincide with the results of the analysis of the concrete cover thickness distribution. The lowest average value of the concrete cover thickness with a simultaneous high coefficient of variation was observed for the slab at level "-1". This was directly related to the shorter time needed to neutralize the concrete. This was confirmed by the results of the carbonation test (test using a 1\% phenolphthalein solution) and phase composition analysis (X-ray diffraction analysis). Loss of protective properties of concrete cover results in a higher probability of corrosion of the reinforcement, which was registered by the GP-5000 GalvaPulse ${ }^{\mathrm{TM}}$ set in the case of a reinforced concrete slab at the "-1" level.

In the case of reinforced concrete column, a thick layer of plaster (locally exceeding even $5 \mathrm{~cm}$ ) limited the rate of destruction of the structure. Unfortunately, due to the lack of project documentation (except for those included in publication [1]), a broader comparison of the presented results with the design assumptions was not possible.

In summary, condition of reinforcement and concrete in the tested elements after 34 years of use was good and appropriate considering the time of use of the structure. 


\section{References}

1. E. Modrzejewski, J. Radkiewicz, M. Sieczkowski, Inżynieria i budownictwo, 3, 89-94 (1986) [in Polish]

2. E. Banachowska, Środowisko Mieszkaniowe - Housing Enviroment., 14, pp. 106-117 (2015) [in Polish]

3. S. Ahmad, Cem. Conc. Comp., 25, pp. 459-473 (2003)

4. M. Jaśniok, T. Jaśniok, Przegląd Budowlany, 6, pp. 30-36 (2007) [in Polish]

5. H.W. Song, V. Saraswathy, Inter. Jour. of Electroch. Science, 2, pp. 1-28 (2007)

6. J. Hoła, K. Schabowicz, Przeglad metod badawczych $w$ zastosowaniu do diagnostyki $i$ monitoringu obiektów budowlanych (Proceedings of XII Conference „Warsztaty Pracy Rzeczoznawcy Budowlanego », pp. 60-80, 2012) [in Polish]

7. W. Raczkiewicz, A. Wójcicki, Przegląd Spawalniczy, 11, pp. 28-33 (2017) [in Polish]

8. W. Raczkiewicz, A. Wójcicki, Evaluation of effectiveness of concrete coat as a steel bars protection in the structure - galvanostatic pulse method (Proceedings of the $26^{\text {th }}$ International Conference Metallurgy and Materials, 1, pp. 1425-1431, 2017)

9. Online : http://www.germann.org/TestSystems/GalvaPulse/GalvaPulse.pdf, 2009

10. PN-EN 13295:2005: Products and systems for the protection and repair of concrete structures - Test methods - Determination of resistance to carbonation

11. PN-EN 14630:2007: Products and systems for the protection and repair of concrete structures. Test methods. Determination of carbonation depth in hardened concrete by the phenolphthalein method

12. D. Urbanowicz, M. Warzocha, Przegląd Budowlany, 5, pp. 32-35 (2015) [in Polish]

13. A. Zybura, M. Jaśniok, T. Jaśniok, Diagnostyka konstrukcji żelbetowych. Badania korozji zbrojenia $i$ właściwości ochronnych betonu (PWN, Warszawa, 2011) [in Polish]

14. P. Tworzewski, Przegląd Budowlany, 11, pp. 52-55 (2017) [in Polish]

15. P. Czapik, Z.Owsiak, Chemical corrosion of external stairs - case study, MATEC Web of Conf., 163, 05003 (2018)

16. W. Raczkiewicz, W. Grzmil, Cement Wapno Beton, 4, pp. 311-319 (2017) [in Polish]

17. M. Auroy, S. Poyet, P.L. Bescop, J.M. Torrenti, T. Charpentier, M. Moskura, X. Bourbon, Cem. Concr. Res., 109, pp. 64-80 (2018)

18. J.H. Seo, S.M. Park, H.K. Lee, Cem. Concr. Res., 109, pp. $81-89$ (2018)

19. Li Shuangxin, Constr. Build. Mater., 123, pp. 226-234 (2016)

20. A. Morandeau, M. Thiéry, P. Dangla, Cem. Concr. Res., 56, pp. 153-170 (2014) 